\title{
EFFECT OF SALINITY STRESS ON GROWTH AND MACRONUTRIENTS UPTAKE OF SOME EGYPTIAN BARLEY LANDRACES ((Hordeum vulgare L.). \\ Abdeen ,S.A. ${ }^{1}$; A.H. Rizk ${ }^{1}$ and S. M. El-Hamamsy ${ }^{2}$ \\ ${ }^{1}$ Department of Soils and Water, Faculty of Agriculture, Al- Azhar University, Cairo, Egypt. \\ ${ }^{2}$ Department of Biochemistry, Faculty of Agriculture, Al- Azhar University, Cairo, Egypt.
}

\begin{abstract}
In this study the effect of salinity stress on growth and macronutrient uptake of some barley landraces ((Hordeum vulgare L.) grown in sandy loam soil were investigated. The main purpose of this study was carried out to evaluate three Egyptian barley landraces i.e. (L2, L6 and L10) for salinity tolerance. The plants were irrigated by using saline water with different concentration $(0,50.100$ and $150 \mathrm{mM}$ $\mathrm{NaCl}$ ) for 60 days. A pot experiment was conducted to achieve this study. Results indicated that increased salinity caused a significant reduction in percentage of fresh and dry weights of barley plants. Soil $\mathrm{pH}$ and EC values were increased as a salinity level of irrigation water increased. Soluble $\mathrm{Na}^{+}$concentration were increased with increasing $\mathrm{NaCl}$ levels, whereas $\mathrm{Ca}, \mathrm{Mg}$ and $\mathrm{K}$ in soil were decrease as a result of increasing the concentration of $\mathrm{NaCl}$ in irrigation water. That is true for all landraces. In addition, the values of $\mathrm{N}, \mathrm{P}$ and $\mathrm{K}$ content in barley landraces were decreased with increasing salinity levels. Also the N, P and K uptake were significant decreased by increasing salinity levels. Generally, the results clearly showed that landrace L2 had the highest salt tolerance compared with landraces L6 and L10.
\end{abstract}

Keywords: Saline stress, barley, macronutrient uptake.

\section{INTRODUCTION}

Salinity is one of the most important problem affecting seed germination and plant growth especially in many area of the world. Barley (Hordeum vulgare L.) is considered to be the most salinity tolerant among cereals (Belaid and Morris, 1991). Salinity stress affects nutrient uptake and metabolic activities in plant (Singh and Hoque, 2001). Plant growth usually decreases by increasing $\mathrm{NaCl}$ concentration in the medium. Naseer et al., (2001) reported that the germination percentage, root and shoot length and fresh and dry weights were decreased in barley cultivars by increasing salinity levels. According to Grattan and Grieve (1999) that the direct effect of salts on plant growth may be divided into three broad categories: (i) a reduction in the osmotic potential of the soil solution that reduces plant available water, (ii) a deterioration in the physical structure of the soil such that water permeability and soil aeration are diminished, and (iii) increase in the concentration of certain ions that have an inhibitory effect on plant metabolism (specific in toxicity and mineral nutrient deficiencies). It is also known that high salt concentrations are toxic and limit growth because nutrients are proportionally less available or create physiological drought as a consequence of the high osmotic pressure of the soil solution (Fageria, et al., 
1991). Salinity generally inhibits plant growth and productivity (Al-Karaki, 2000).More precisely, detrimental effects of salinity on plant growth result from direct effects of ion toxicity or indirect effects of saline ions on soil water potential, which cause soil/ plant osmotic imbalances. Several authors summarized that salt stress significantly decreased shoot, root and total dry matter of corn plants, and noticed an increasing degree of reduction in dry matter production with increasing salinity levels (Bar-Tal, et al., 1991). Salinity reduces plant growth and yield by two mechanisms, osmotic stress and ion cytotoxicity (Munns and Tester 2008). Munns et al. (1995) proposed a twophase model of salt injury where growth is initially reduced by osmotic stress and then by $\mathrm{Na}^{+}$toxicity. However, some uncertainty exists regarding the relative importance of the two mechanisms. This is due to the difficulty in separating the osmotic effect from specific ion effects because of the overlap in the development of the two types of stresses during the development of salinity stress.

The saline growth medium causes many adverse effects on plant growth, which are due to a low osmotic potential of soil solution (osmotic stress), specific ion effects (salt stress), nutritional imbalances, or a combination of these factors (Marschner 1995). The deleterious effects of salinity on plant growth is attributed to the decrease in osmotic potential of the growing medium, specific ion toxicity and nutrient ion deficiency by disrupting potassium $(\mathrm{K}+)$ nutrition, which can be a result of inorganic ion $\left(\mathrm{Na}^{+}, \mathrm{Cl}^{-}\right.$, and $\mathrm{K}^{+}$) and compatible organic solute accumulations (soluble carbohydrates, amino acids, proline, betaines, etc.) (Luo et al., 2005). Plants require macro and micro elements to grow. In soil, micronutrients are not always present in the solution and their availability is limited due to several factors, which mainly limit their solubility. Reduced growth under saline conditions is a common response of many plant species including barley (Mahmood et al., 1996). Salt stress had a negative effect on plant growth and caused reduction of dry weight in all maize cultivars. Reduction in growth is one of the potential criteria, as indicated in some earlier studies (Hichem et al., 2009). The main objective of this study is to evaluate growth and macronutrient uptake of some three Egyptian Barley landraces for salt tolerances.

\section{MATERIAS AND METHODS}

In order to study the effect of salinity on growth and macronutrient uptake of three barley landraces (Hordeum vulgare L.) (L2, L6, L10), a Pot experiment was carried out at the farm of soils and water department, Faculty of Agriculture, Al- Azhar University, Nasr city Cairo Egypt. Barley landraces were obtained from Field Crops Research Institute and National Gene Bank (NGB), Agricultural Research Center (ARC), Giza, Egypt. The landraces were analyzed in biochemistry department, Faculty of Agriculture, Al-Azhar University, Cairo, Egypt. Four $\mathrm{NaCl}$ concentrations (0, 50, 100 and $150 \mathrm{mM}$ ) were added. Plastic pots filled with $7 \mathrm{~kg}$ sandy loam soil. 10 seeds of all landraces were planted in every pot and moisture content of pots was kept approximately at field capacity. The cultivated plants were fertilized with 
ammonium sulfate, super phosphate and K- sulfate according to the general recommendation dose of Ministry of Agriculture. After 60 days from planting, barley shoots of each treatment were cut just one $\mathrm{cm}$ above the soil surface and prepared for analysis. Soil samples from each pot were taken after harvesting, air- dried, crushed and passed through a $2 \mathrm{~mm}$ sieve and kept for soil analysis. The characteristics of the investigated soil, i.e. Particle size distribution, Soil $\mathrm{pH}, \mathrm{EC}$, soluble cations and anions, available $\mathrm{N}, \mathrm{P}, \mathrm{K}$ were determined (Page et al., 1982 and Klute, 1986). N, P and K were estimated in the plant digest, Cottenie et al. (1982). Total seeds storage protein, carbohydrate and ash were determined by near infra analyzer (NIR), according to Zhao et al. (2005). Total lipids and the moisture content were determined as recommended the proceeding outline by A.O.A.C. (1990). The statistical analysis for all data, which obtained was carried out and differences between means were calculated using L.S.D test according to Steel and Torrie (1980). Some physical and chemical properties of the studied soil are presented in Table 1.

Table 1 Some physical and chemical properties of the studied soil

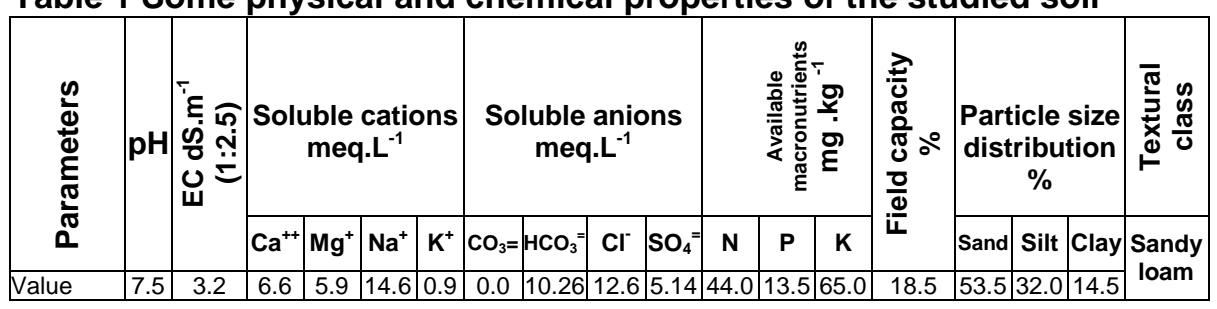

\section{RESULTS AND DISCUSSION}

\section{Chemical composition of three Egyptian barley landraces}

Grain proteins content and carbohydrates are considered the most important characteristics determining grain quality landraces. (Gooding et al., 2003). Data in Table 2 show that the highest value of total carbohydrate content was recorded in landrace 2 . The increment was highly significant compared with other landraces. On the other hand the lowest value was found in landrace 10. Also, data revealed that the highest value of fiber content noticed in L6 while the lowest value found in L10.Addition that L10 had the highest value of crude proteins and $L 6$ had the lowest value. Concerning of Lipids content, L6 recorded the highest value while the lowest recorded in L2.

Table 2 Chemical composition of used barley landraces.

\begin{tabular}{|l|c|c|c|c|c|c|}
\hline $\begin{array}{l}\text { Barley } \\
\text { landraces }\end{array}$ & $\begin{array}{c}\text { Total } \\
\text { Carbohydrates }\end{array}$ & Fiber & Ash & Proteins & Moisture & Lipids \\
\hline L2 & 43.06 & 5.08 & 2.19 & 12.84 & 10.21 & 0.85 \\
\hline L6 & 40.75 & 5.26 & 2.26 & 12.43 & 9.82 & 0.91 \\
\hline L10 & 36.13 & 4.89 & 2.34 & 13.50 & 9.96 & 0.87 \\
\hline LSD at 5\% & 3.69 & N.S & N.S & 0.45 & N.S & N.S \\
\hline
\end{tabular}




\section{Soil chemical properties after barley harvest}

Soil $\mathrm{pH}$ is the most important parameter which shows the over all changes in soil chemical properties. The data in Table 3 show that $\mathrm{pH}$ values increased as a salinity level of irrigation water increased. The maximum value of $\mathrm{pH}$ (7.4) was recorded under the higher levels of saline irrigation water (150 NaCl mM) while, minimum $\mathrm{pH}(7.11)$ was noted at control. The values of soil $\mathrm{pH}$ ranged from 7.11 to 7.4 with all landraces. In this concern Magdi et al., (2010) found that irrigation with saline water $(\mathrm{NaCl}$ at 50 or $100 \mathrm{mM})$ significantly increased the values of $\mathrm{pH}$ in the soil samples compared with the control. Also the analysis of soil showed that irrigation with saline water increase the total soluble salts in the soil samples after barley harvest. Soil electrical conductivity increased as a result of increasing salinity levels of irrigation water. This finding is in agreement with those obtained by Ragab (2001) He observed that, there was a progressive and significant increase in soil salinity values as the salinity of irrigation water increases. The highest value recorded $12.2 \mathrm{dSm}^{-1}$ for salinity level $150 \mathrm{mM} \mathrm{NaCl}$ treatment, and the lowest value was obtained $3.5 \mathrm{dSm}^{-1}$ for salinity level control treatment for L10. Also the same trend was found for all landraces.

Table 3 Some soil properties as affected by levels of saline irrigation water $(\mathrm{NaCl})$ after barley harvest.

\begin{tabular}{|c|c|c|c|c|c|c|c|c|c|c|c|}
\hline \multirow{2}{*}{ Landraces } & \multirow{2}{*}{$\underset{\mathrm{M}}{\mathrm{NaCl} \mathrm{m}}$} & \multirow{2}{*}{$\mathrm{pH}$} & \multirow{2}{*}{$\begin{array}{c}\text { EC } \\
\text { dS. } \mathbf{m}^{-1}\end{array}$} & \multicolumn{4}{|c|}{ Cations meq. $\mathrm{L}^{-1}$} & \multicolumn{4}{|c|}{ Anions meq. $\mathrm{L}^{-1}$} \\
\hline & & & & $\mathrm{Ca}^{++}$ & $\mathrm{Mg}^{++}$ & $\mathrm{Na}^{+}$ & $\mathbf{K}^{+}$ & $\mathrm{CO}_{3}$ & $\mathrm{HCO}_{3}$ & $\mathrm{Cl}^{-}$ & $\mathrm{SO}_{4}$ \\
\hline \multirow{4}{*}{ L2 } & 0.0 & 7.11 & 3.60 & 8.50 & 4.60 & 16.50 & 2.80 & 0.00 & 8.20 & 15.50 & 8.70 \\
\hline & 50 & 7.20 & 6.90 & 5.60 & 3.50 & 44.70 & 2.00 & 0.00 & 5.11 & 43.50 & 7.09 \\
\hline & 100 & 7.35 & 9.70 & 4.20 & 2.60 & 76.50 & 1.50 & 0.00 & 4.30 & 74.70 & 5.80 \\
\hline & 150 & 7.40 & 11.80 & 2.80 & 1.80 & 90.50 & 0.90 & 0.00 & 3.20 & 87.20 & 5.60 \\
\hline \multirow{4}{*}{ L6 } & 0.0 & 7.14 & 3.50 & 8.80 & 4.70 & 15.00 & 3.90 & 0.00 & 8.40 & 16.00 & 8.00 \\
\hline & 50 & 7.25 & 7.10 & 6.40 & 4.11 & 48.00 & 3.00 & 0.00 & 7.20 & 46.50 & 7.81 \\
\hline & 100 & 7.40 & 9.60 & 4.00 & 2.30 & 73.00 & 2.00 & 0.00 & 6.50 & 68.00 & 6.80 \\
\hline & 150 & 7.40 & 11.40 & 3.50 & 1.50 & 98.40 & 1.40 & 0.00 & 5.40 & 93.00 & 6.40 \\
\hline \multirow{4}{*}{ L10 } & 0.0 & 7.13 & 3.50 & 7.80 & 5.00 & 16.10 & 3.20 & 0.00 & 9.11 & 15.70 & 7.29 \\
\hline & 50 & 7.20 & 8.10 & 7.11 & 4.20 & 49.60 & 3.00 & 0.00 & 7.90 & 49.20 & 6.51 \\
\hline & 100 & 7.40 & 10.20 & 5.20 & 2.90 & 76.3 & 2.11 & 0.00 & 6.90 & 74.00 & 5.61 \\
\hline & 150 & 7.40 & 12.20 & 4.20 & 2.00 & 97.00 & 1.80 & 0.00 & 5.60 & 96.00 & 3.40 \\
\hline
\end{tabular}

Concerning soluble cations and anions data show that the concentration of soluble $\mathrm{Ca}^{++}, \mathrm{Mg}^{++}$and $\mathrm{K}^{+}$in soil decreased as a result of increasing the concentration of $\mathrm{NaCl}$ in irrigation water. That is true for all landraces. The highest values of $\mathrm{Ca}^{++}, \mathrm{Mg}^{++}$and $\mathrm{K}^{+}$for $\mathrm{L} 2$. were $8.5,4.6$ and 2.8 meq. $\mathrm{L}^{-1}$, respectively. While the lowest values were $2.8,1.8$ and 0.9 meq. $\mathrm{L}^{-1}$ respectively. In L6. The highest values of $\mathrm{Ca}^{++}, \mathrm{Mg}^{++}$and $\mathrm{K}^{+}$were 8.8, 4.7 and 3.9 meq. $L^{-1}$, respectively. While the lowest values were $3.5,1.5$ and 1.4 meq/L, respectively. In L10. The highest value of $\mathrm{Ca}^{++}, \mathrm{Mg}^{++}$and $\mathrm{K}^{+}$were $7.8,5$ and $3.2 \mathrm{meq} / \mathrm{L}$, respectively. While the lowest value were $4.2,2$ and $1.8 \mathrm{meq} / \mathrm{L}$, respectively. But soluble sodium content in the studied soil for all landraces increased by increasing sodium content in irrigation water; this could be attributed to the higher adsorption capacity of sodium. Regard to soluble $\mathrm{HCO}_{3}^{-}$and $\mathrm{SO}_{4}{ }_{4}$, generally, increasing salinity levels of irrigation 
water effected on sulphat and bicarbonate content in the studied soil, the highest value were found in control while the lowest one was found for salinity level $150 \mathrm{mM} \mathrm{NaCl}$ treatment. The precedent data are in agreement with those obtained by Magdi et al., (2010) who found that irrigation with saline water $\left(\mathrm{NaCl}\right.$ at 50 or $100 \mathrm{mM}$ ) significantly reduced $\mathrm{Ca}^{++}, \mathrm{Mg}^{++}, \mathrm{K}^{+}$, $\mathrm{HCO}_{3}{ }^{-}$and $\mathrm{SO}_{4}{ }^{2}$, while significantly increased the contents of $\mathrm{Na}^{+}, \mathrm{Cl}^{-}, \mathrm{pH}$, and EC in the soil samples compared with the control.

\section{Fresh and dry weight}

Generally, plant growth and development are adversely affected by salinity. Data in Table 4 show that the reduction in fresh and dry weight of barley plant was significantly increased with increasing salinity levels in irrigation water. In this concern, Shafi et al., (2009) found that salinity lead to disturbances in plant metabolism, which consequently led to reduction of plant growth. The results clearly showed that increases in salinity were significantly decreased growth of barley plants.

Table (4)Effect of saline irrigation water on fresh and dry weight(g. $\left.\operatorname{pot}^{-1}\right)$ of barley plant

\begin{tabular}{|c|c|c|c|c|c|}
\hline \multirow[b]{2}{*}{ Landraces } & \multirow{2}{*}{$\begin{array}{c}\mathrm{NaCl} \\
\mathrm{m} \mathrm{M}\end{array}$} & \multicolumn{2}{|c|}{ Fresh weight } & \multicolumn{2}{|c|}{ Dry weight } \\
\hline & & g.pot ${ }^{-1}$ & $\begin{array}{c}\text { Decrease }^{*} \\
\%\end{array}$ & g.pot ${ }^{-1}$ & $\begin{array}{c}\text { Decrease }^{\star \star} \\
\%\end{array}$ \\
\hline \multirow{4}{*}{ L2 } & 0.0 & 41.55 & - & 7.80 & - \\
\hline & 50 & 40.00 & 3.73 & 7.44 & 4.62 \\
\hline & 100 & 34.65 & 16.61 & 6.95 & 10.9 \\
\hline & 150 & 29.33 & 29.41 & 6.22 & 20.26 \\
\hline \multicolumn{2}{|l|}{ mean } & 36.38 & - & 7.10 & - \\
\hline \multirow{4}{*}{ L6 } & 0.0 & 38.62 & - & 7.43 & - \\
\hline & 50 & 38.00 & 1.61 & 7.00 & 5.79 \\
\hline & 100 & 35.70 & 7.56 & 7.00 & 5.79 \\
\hline & 150 & 24.42 & 36.77 & 5.75 & 22.61 \\
\hline \multicolumn{2}{|l|}{ mean } & 34.18 & - & 6.79 & - \\
\hline \multirow{4}{*}{ L10 } & 0.0 & 40.22 & - & 7.36 & - \\
\hline & 50 & 37.54 & 6.66 & 6.94 & 5.71 \\
\hline & 100 & 32.41 & 19.42 & 6.22 & 15.49 \\
\hline & 150 & 22.63 & 43.73 & 5.40 & 26.63 \\
\hline \multicolumn{2}{|l|}{ mean } & 33.20 & - & 6.48 & - \\
\hline \multirow[t]{3}{*}{ LSD at $5 \%$} & $A$ & 0.15 & - & 0.22 & - \\
\hline & $\mathrm{B}$ & 0.18 & - & 0.26 & - \\
\hline & $\mathrm{AB}$ & 0.31 & - & N.S & - \\
\hline
\end{tabular}

$\mathrm{A}=$ Landraces and $\mathrm{B}=\mathrm{NaCl} \mathrm{mM}$

* Fresh weight decrease $\%=100 \times[1$ - (fresh weight treated with $\mathrm{NaCl}$ fresh weight control)]

** Dry weight decrease $\%=100$ x [1 - (dry weight treated with $\mathrm{NaCl} /$ dry weight control)]

These results are in agreement with those obtained by Sayed (2015) found that fresh and dry weight gradually decreased as the salt concentration increased. However, barley cultivars differ in their sensitivity or tolerance to salts. The percentages of fresh and dry weight were significantly decreased as a result of salt stress in all barley landraces. The maximum percentage 
was recorded under control level and minimum at the highest salinity level. However, maximum percentage of fresh and dry weight was recorded in L2 in all salinity levels. Also, minimum percentage was recorded in L10 under the same levels. The highest decreasing percentage of fresh and dry weight recorded 43.74 and $26.63 \%$, respectively.

On the other hand the best landrace to tolerance salinity was L2. The highest decreasing percentage of fresh and dry weight recorded 29.41 and 20.26 $\%$ respectively. These results are in agreement with those obtained by Hichem et al., (2009) who found that growth reduction as associated with salt stress in different maize cultivars at different growth stages. Furthermore, growth reducing effects of different saline regimes in hydroponic culture system were also observed by Chen et al., (2007) in different bean cultivars and they reported that different cultivars showed differential response to salt stress. Generally, the maximum percentage of fresh and dry weight recorded under control level and minimum at the highest salinity level of all landraces. According to Haggi et al., (1999) the depressive effect of salt on the growth is related to the osmotic potential of the soil solution around the roots, an increase in the accumulation of some ions in harmful concentrations in tissues and a modification of the nutritional statute of the essential ions to the growth and the development. The increase of soil salinity is translated by an immediate reduction of shoot growth. This is may be due to salinity reduces the water potential of soil solution, which prevents the efficient water supply to the plants. Therefore, saline habitats receiving large amounts of salts in root cells that limit the germination, seedling growth and establishment. (Jamian et al., 2014).

\section{NPK content and uptake}

Generally, data in Table 5 show that the N, P and $\mathrm{K}$ content were decreased with increasing the concentration of $\mathrm{NaCl}$. Also the uptake of NP and $\mathrm{K}$ were significantly decreased with increasing the concentration of $\mathrm{NaCl}$. This is may be due to higher salinity may affect different metabolic processes. The concentrations of soluble salts through their high osmotic pressures affect plant growth by restricting the uptake of water by plant roots. High salinity can also cause nutrient imbalances. In this concern Grattan and Grieve (1999) revealed that the content of some macro nutrients in plant tissue depend on the level of salinity, plant species (cultivar) and developmental stage of plant. The data indicated that both barley landraces grown in sandy loam soil affected by the high levels of salinity. Various authors have attributed this reduction to $\mathrm{Cl}^{-}$antagonism of $\mathrm{NO}_{3}{ }^{-}$(Bar et al., 1997) while others attributed the response to salinity's effect on reduced water uptake (Lea-Cox and Syvertsen, 1993). The nitrate influx rate or the interaction between $\mathrm{NO}_{3}{ }^{-}$and $\mathrm{Cl}^{-}$has been reported to be related to the salt tolerance of the species under investigation. In most cases, salinity decreased the concentration of $P$ in plant tissue (Kaya et al., 2001), but the results of some studies indicate salinity either increased or had no effect on $P$ uptake (Ansari, 1990). The reduction in $\mathrm{P}$ availability in saline soils was suggested by Sharkey et al., (1992) to be a result of ionic strength effects that reduce the activity of phosphate. In L2 the lowest values of NP and K content 
were observed in the highest levels of $\mathrm{NaCl}(150 \mathrm{mM})$. The values recorded: $1.55,0.20$, and $1.11 \%$, compared with $1.65,0.32$ and 1.5 as control, respectively. Also, the same trend observed by the uptake of these elements. Concerning of L6, the data in table 3 also revealed that the lowest values of $\mathrm{NP}$ and $\mathrm{K}$ content and uptake were recorded at $150 \mathrm{mM}$ of $\mathrm{NaCl}$ compared with other treatments. The values recorded, $1.4,0.2$ and $1.2 \%$, compared with $1.6,0.25$ and $1.41 \%$ as control, respectively. Regarding to L10, the lowest values of $\mathrm{N}, \mathrm{P}$ and $\mathrm{K}$ content were recorded $1.3,0.2$ and 1.10 $\%$ compared with 1.6, 0.3 and $1.35 \%$ as control respectively. The mean values of NP K uptake for L6 and L10 were recorded 10.41, 1.58, 8.95 mg.plant ${ }^{-1}$ and 9.31, 1.68 .12 mg.plant $^{-1}$, respectively, compared with L2 which recorded $11.62,1.86$ and $9.46 \mathrm{mg} /$ plant. These data are in agreement with those obtained by Mer et al., (2000) who found that macronutrients uptake by barley plants were decreased as a result of high concentrations of salts.

Table 5 NPK content and uptake of barley plant as affected by salinity levels in irrigation water.

\begin{tabular}{|c|c|c|c|c|c|c|c|}
\hline \multirow[b]{2}{*}{ Landraces } & \multirow[b]{2}{*}{$\begin{array}{c}\mathrm{NaCl} \\
\mathrm{m} \mathrm{M}\end{array}$} & \multicolumn{2}{|c|}{$\mathbf{N}$} & \multicolumn{2}{|c|}{$\mathbf{P}$} & \multicolumn{2}{|c|}{$\mathbf{K}$} \\
\hline & & $\begin{array}{c}\text { Content } \\
\%\end{array}$ & $\begin{array}{c}\text { Uptake } \\
\text { mg.plant }^{-1}\end{array}$ & $\begin{array}{c}\text { Content } \\
\%\end{array}$ & $\begin{array}{c}\text { Uptake } \\
\text { mg.plant }^{-1}\end{array}$ & $\begin{array}{c}\text { Content } \\
\%\end{array}$ & $\begin{array}{c}\text { Uptake } \\
\text { mg.plant }^{-1}\end{array}$ \\
\hline \multirow{4}{*}{ L2 } & 0.0 & 1.65 & 12.87 & 0.32 & 2.50 & 1.50 & 11.70 \\
\hline & 50 & 1.73 & 12.87 & 0.29 & 2.16 & 1.39 & 10.34 \\
\hline & 100 & 1.60 & 11.12 & 0.22 & 1.53 & 1.28 & 8.90 \\
\hline & 150 & 1.55 & 9.64 & 0.20 & 1.24 & 1.11 & 6.90 \\
\hline \multicolumn{2}{|l|}{ mean } & 1.63 & 11.62 & 0.26 & 1.86 & 1.32 & 9.46 \\
\hline \multirow{4}{*}{ L6 } & 0.0 & 1.60 & 11.89 & 0.25 & 1.86 & 1.41 & 10.48 \\
\hline & 50 & 1.60 & 11.20 & 0.27 & 1.89 & 1.33 & 9.31 \\
\hline & 100 & 1.50 & 10.50 & 0.20 & 1.40 & 1.30 & 9.10 \\
\hline & 150 & 1.40 & 8.05 & 0.20 & 1.15 & 1.20 & 6.90 \\
\hline \multicolumn{2}{|l|}{ mean } & 1.53 & 10.41 & 0.23 & 1.58 & 1.31 & 8.95 \\
\hline \multirow{4}{*}{ L10 } & 0.0 & 1.60 & 11.78 & 0.30 & 2.21 & 1.35 & 9.94 \\
\hline & 50 & 1.40 & 9.72 & 0.25 & 1.74 & 1.30 & 9.02 \\
\hline & 100 & 1.40 & 8.71 & 0.22 & 1.37 & 1.22 & 7.59 \\
\hline & 150 & 1.30 & 7.02 & 0.20 & 1.08 & 1.10 & 5.94 \\
\hline \multicolumn{2}{|l|}{ mean } & 1.43 & 9.31 & 0.24 & 1.60 & 1.24 & 8.12 \\
\hline \multirow[t]{3}{*}{ LSD at $5 \%$} & $\mathrm{~A}$ & 0.12 & 0.21 & N.S & 0.06 & 0.06 & 0.19 \\
\hline & $\mathrm{B}$ & 0.14 & 0.34 & 0.04 & 0.07 & 0.07 & 0.22 \\
\hline & $A B$ & N.S & 0.41 & N.S & 0.11 & N.S & 0.38 \\
\hline
\end{tabular}

\section{A= Landraces}

$\mathrm{B}=\mathrm{NaCl} \mathrm{mM}$

\section{CONCLUSION}

In general, it can be concluded that salinity of irrigation water negatively affected growth and macronutrient uptake of the barley landraces. The maximum percentage of fresh and dry weight recorded under control level and minimum at the highest salinity level. However, maximum percentage of fresh and dry weight recorded in $L 2$ in all salinity levels followed with $L 6$ and $\mathrm{L} 10$. Also $\mathrm{pH}$ values increased as a salinity level of irrigation water increased 
compared with the control. In addition to soluble cations and anions in soil after harvest decreased as a result of increasing the concentration of $\mathrm{NaCl}$ in irrigation water. The result also pointed out clearly that salinity changed ion uptake in barley shoots. Salinity caused a significant decreasing in N, P and $\mathrm{K}$ uptake. Also, the results showed that $\mathrm{L} 2$ has the highest tolerance compared with landraces L6 and L10 under the same condition of salt stress. Also, it is the best landraces to NP and K uptake under salinity levels compared with other landraces.

\section{REFERENCES}

Al- Karaki, G.N. (2000) Growth, water use efficiency, and sodium and potassium acquisition by tomato cultivars grown under salt stress. J.Plant Nutrition, 23 (1), 1-8.

Ansari, R. (1990) Growth and chemical composition of barley (Hordeum vulgare) cultivars on saline substrate as compared with a salt tolerant variety of wheat (Triticum aestivum). In: Plant Nutrition Physiology and Application (Ed.: M.L. von Beusichem). Kluwer Academic Publishers, The Netherlands. pp. 463-467.

A.O.A.C. (1990) Official Methods of Analysis of the Association of Official Agriculture Chemists. 15th ed. Washington D.C., U.S.A.

Bar, Y., Kafkafi, U. and Lahav, E. (1997) Nitrate nutrition as a tool to reduce chloride toxicity in avocado. Yearbook South African Avocado Growers Association, 10, 47-48.

Bar-Tal, A., Feigenbaum, S. and Sparks D. (1991) Potassium salinity interactions in irrigated corn. Irrigat. Sci., 12 (1), 27-36.

Belaid, A. and Morris, M. (1991) Wheat and barley production in rain fed marginal environments of west Asia and North Africa. Problems and prospects. CIMMYT Economics Working Paper. Pp: 91.

Chen, C., Tao, C., Peng, H. and Ding,Y. (2007) Genetic analysis of salt stress responses in asparagus bean (Vigna unguiculata (L.) ssp. sesquipedalis Verdc.). J. Hered., 98(7): 655-665.

Cottenie, A., Verloo, M., Velghe, G. and Comerlynk, R. (1982) Chemical analysis of plant and soil. Laboratory of analytical and agro-chemistry state university, Ghent, Belgium.

Fageria, N.K., Baligar, V.C. and Jones, C.A. (1991) Growth and mineral nutrition of field crops. Marcel Dekker Inc., Madison Avenue, New York.

Gooding, M. J., Ellis, R. H.;Shewry, P. R. and Schofield, J. D. (2003). Effects of restricted water availability and increased temperature on the grain filling, drying and quality of winter wheat. J. Cereal Sci, 37: 295-309.

Grattan, S.R. and Grieve, C.M. (1999) Salinity-mineral nutrient relations in horticultural crops. Sci. Hort., 78, 127-157.

Haggi, M., Lachaal, M., Soltani, M. and Abdelli,Y.( 1999) Response of the plants to the saline stress: Ecophysiologic and Biochemical aspects of the tolerance to salt. In Annual meeting of the EUCA, Sustainable utilization of Halophytes. Agadir 5 to 15 April. 
Hichem, H., Mounir, D. and Naceurc, E. (2009) Differential responses of two maize (Zea mays L.) varieties to salt stress: Changes on polyphenols composition of foliage and oxidative damages. Ind. Crops Prod., 30: 144-151.

Jamian, S., Mehrani,S. Asilan,K. , Tabrizi,A., and Goharian,A. (2014) The effects of salinity stress on seed germination and seedling growth of three medicinal Plants. Intl J Farm and Alli Sci. 3 (3): 299-303.

Kaya, C., Kirnak, H. and Higgs, D. (2001) Enhancement of growth and normal growth parameters by foliar application of potassium and phosphorus in tomato cultivars grown at high $(\mathrm{NaCl})$ salinity. J. Plant Nutr., 24, 357-367.

Klute,A. (1986) Methods of Soil Analysis. Part 1. Physical and mineralogical Methods $2^{\text {nd }}$ Ed., Amer. Soc. Agron. Monograph No. 9 Madison,Wisconsin,USA.

Lea-Cox, J.D. and Syvertsen, J.P. (1993) Salinity reduces water use and nitrate- N-use efficiency of citrus. Ann. Bot., 72, 47-54.

Luo, Q., Yu B., and Liu, Y. (2005) Differential sensitivity to chloride and sodium ions in seedlings of Glycine $\max$ and $G$. soja under $\mathrm{NaCl}$ stress. J Plant Physiol. 162(9): 1003-1012.

Magdi, T. Abdelhamid1, M. Shokr, B. and Bekheta, M. (2010) Effects of induced salinity on four vicia faba cultivars differing in their broomrape tolerance. IWTC 14, Cairo, Egypt 421-427.

Mahmood, K., Malik, K., Lodhi ,M. and Sheikh, K. (1996) Seed germination and salinity tolerance in plant speciecies growing on saline waste lands. Biol. Plant., 38: 309-315.

Marschner, H. (1995) Mineral Nutrition of Higher Plants. Academic Press, London. $889 \mathrm{p}$.

Mer, R. K., Pajith, P. K. Pandya, D. M. and Pandey, A. N. (2000) Effect of salts on germination of seeds and growth of young plants of Hordeum valgare, Triticum aestivum, and Brassica juncea. J. Agro. Crop Sci. 185(4):209-217.

Munns, R. and Tester, M. (2008) Mechanisms of salinity tolerance. Annual Review of Plant Biology 59: 651-681.

Munns, R., Schachtman, D. and Condon, A. (1995) The significance of a two phase growth response to salinity in wheat and barley. Australian Journal of Plant Physiology 22, 561-569.

Naseer, Sh., Nisar, A., and Ashraf, M. (2001) Effect of salt stress on germination and seedling growth of barley (Hordeum vulgare L.). Pakistan J. Biol. Sci. 4(3): 359-360.

Page, A. L., Miller, R.H. and Keeny, D.R. (1982) Methods of Soil Analysis. Part П. Chemical and microbiological properties $2^{\text {nd }}$ Ed., Amer. Soc. Agron. Monograph No. 9 Madison,Wisconsin,USA.

Ragab, A.A. (2001) Physical properties of some Egyptian soils. Ph.D. Thesis, Fac. of Agric. Cairo Univ. Egypt. 
Sayed, H. A. (2015) Study of the effect of salt stress on biometric characteristics of barley (Hordeum vulgare L.) (Poaceae). Journal of Medical and Bioengineering. 4 (4) 270-274.

Shafi, M., Raziuddin, J. and Zhang, G. (2009) Effect of cadmium and salinity stresses on growth and antioxidant enzymes activity of wheat genotypes. J. Environ.Toxicol. 82(6): 772-776.

Sharkey, T.D., Vassey, T.L. Vanderveer, P.J. and Vierstra, R.D. (1992). Carbon metabolism enzymes and photosynthesis in transgenic tobacco (Nicotiana tobacum L.) having excess phytochrome. Planta, 185, 287296.

Singh, R.A. and Hoque, M.S. (2001) Changes in growth and metabolic activity in seedling of lentil (Lens culinaris medik) genotypes during salt stress. Indian J. Plant Physiol. 6: 406-410.

Steel, R.G. and Torrie, J.H. (1980). Principle and Procedures of Statistics, a Biometrical Approach. McGraw- Hill Book Company. Second Edit.

Zhao, C.; Liu, L.; Wang, J.; Huang, W.; Song, X. and Li, C. (2005). Predicting grain protein content of winter wheat using remote sensing data based on nitrogen status and water stress. International J. of Appl. Earth Observation and Geoinformation. 7(1): 1-9.

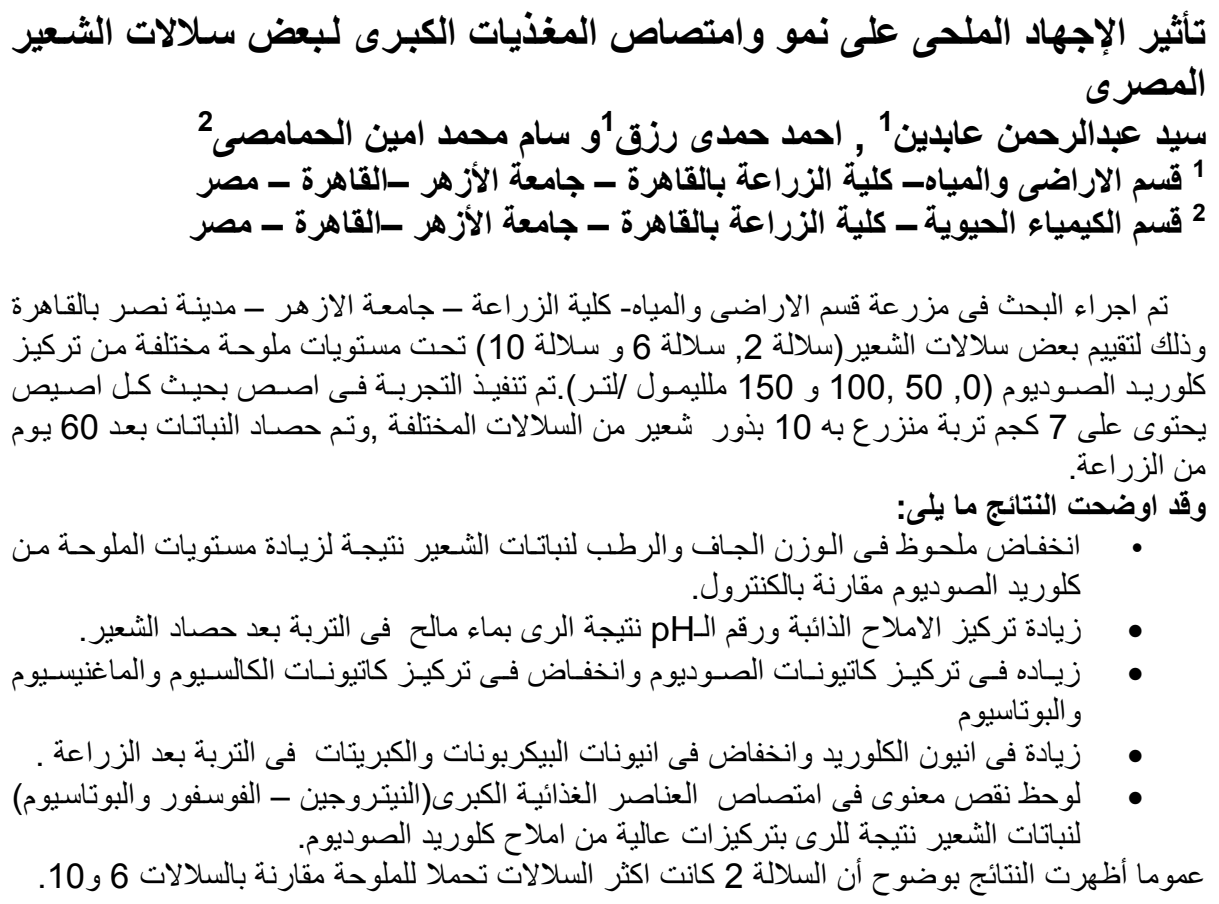

